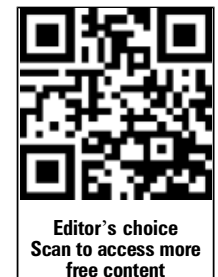

\title{
Genetics of arrhythmogenic right ventricular cardiomyopathy
}

Oscar Campuzano, ${ }^{1}$ Mireia Alcalde, ${ }^{1}$ Catarina Allegue, ${ }^{1}$ Anna Iglesias, ${ }^{1}$
Pablo García-Pavía, ${ }^{2}$ Sara Partemi, ${ }^{3}$ Antonio Oliva, ${ }^{3}$ Vincenzo L Pascali, ${ }^{3}$
Paola Berne, ${ }^{4}$ Georgia Sarquella-Brugada, ${ }^{5}$ Josep Brugada, ${ }^{4}$ Pedro Brugada,
Ramon Brugada

'Department of Medicine, Cardiovascular Genetics Center, University of GironaIdIBGi, Girona, Spain ${ }^{2}$ Department of Cardiology, Hospital Puerta de Hierro, Madrid, Spain

${ }^{3}$ Institute of Legal Medicine, Catholic University, School of Medicine, Roma, Italy ${ }^{4}$ Arrhythmia Unit, Hospital Clinic Barcelona, University of Barcelona, Barcelona, Spain ${ }^{5}$ Arrhythmia Unit, Cardiology Section, Hospital Sant Joan de Déu, University of Barcelona, Barcelona, Spain

${ }^{6}$ Cardiovascular Division, UZ

Brussel-VUB, Brussels, Belgium

\section{Correspondence to} Dr Ramon Brugada, Department of Medicine, Cardiovascular Genetics Center, Institut d'Investigació Biomèdica Girona-IDIBGI, C/Pic de Peguera 15, Girona 17003, Spain; ramon@brugada.org

Received 9 January 2013 Accepted 29 January 2013 Published Online First 6 March 2013

To cite: Campuzano 0 , Alcalde $\mathrm{M}$, Allegue $\mathrm{C}$, et al. $J$ Med Genet 2013:50: 280-289.

\section{ABSTRACT}

Arrhythmogenic right ventricular cardiomyopathy is a rare clinical entity characterised by fibro-fatty replacement of myocardium, mainly involving right ventricular free wall, leading to malignant electrical instability and sudden cardiac death. The disease is inherited in up to $50 \%$ of cases, with incomplete penetrance and variable phenotypic expression. To date, more than 300 pathogenic mutations have been identified in 12 genes, mainly with autosomal dominant inheritance. Here, we focus on recent advances in the genetics of arrhythmogenic right ventricular cardiomyopathy. Despite continuous improvements, current genotype-phenotype studies have not contributed yet to establish a genetic risk stratification of the disease.

\section{INTRODUCTION}

Arrhythmogenic right ventricular cardiomyopathy (ARVC, Online Mendelian Inheritance in Man (OMIM) 107970) is an inheritable structural heart disease first described by Frank et al. ${ }^{1}$ The first comprehensive clinical description of a cohort of ARVC patients was reported in 1982 by Marcus et $a l^{2}$ among adults with ventricular tachyarrhythmias of left bundle branch block morphology. ARVC is characterised by progressive replacement of cardiac myocytes by fibro-fatty tissue, predominantly of the right ventricular (RV), ${ }^{3}$ but in up to $50 \%$ of cases, the left ventricular (LV) may be also involved. ${ }^{4-6}$ Structural alterations are responsible for electrical abnormalities, with or without impaired mechanical function, subsequent ventricular arrhythmias, syncope and sudden cardiac death (SCD). ${ }^{78}$

Current diagnosis is based on the presence of a series of diagnostic criteria (minor and major). Therefore, the RV outflow tract, apex and inflow tract (subtricuspid area) - the 'triangle of dysplasia'show localised/diffuse atrophy with progressive fibrofatty infiltration. The interventricular septum and also frequently the LV myocardium are often involved on a histopathological level. These structural alterations are evaluated by bidimensional echocardiography, cardiac resonance or RV angiography and biopsy characterisation of the myocardial wall. As a result of these morphological alterations, depolarisation and repolarisation abnormalities, ventricular arrhythmias and family history of ARVC and SCD in young individuals (less than 35-years-old) are clinical findings and manifestations of the pathology. Thus, the diagnostic criteria were suggested by a Task Force
(TFC) on ARVC in $1994,{ }^{9}$ and revised in $2010 .{ }^{10}$ The prevalence range is estimated around $1: 2500 /$ $1: 5000$ in the general population, but in Northern Italy and Germany the range increases to 20/ $5000 .^{2}{ }^{11}$ ARVC is recognised as a main cause of SCD in young population under 35 years of age $(15 \%-25 \%),{ }^{12} 13$ especially among athletes, as exercise is a well-known trigger of ventricular arrhythmias and accelerates the development of structural abnormalities in ARVC. ${ }^{14}$ The disease is more penetrant in men $(1.6: 1)$, although gender appears a priori not to harbour adverse effects on long-term survival. ${ }^{15}$ Syncope can be the first manifestation of the disease. ${ }^{16}{ }^{17}$ If the disease is recognised at an early stage and if appropriate treatment is instituted, SCD can be prevented. Recent studies have demonstrated the efficacy of the implantable cardioverterdefibrillator therapy in the prevention of SCD in patients affected by ARVC and history of syncope, haemodynamically unstable sustained ventricular tachycardia (VT) and heart failure ${ }^{78}$ although little data are available on the prophylactic implantation of an implantable cardioverter-defibrillator in patients considered to be at intermediate arrhythmic risk (haemodynamically stable sustained VT, nonsustained VT, severe dilatation and/or dysfunction of the RV, LV or both, and early onset of severe structural disease). ${ }^{19-21}$

In recent years, while there has been continuous progress in genetics of ARVC, little is known about the mechanistic process responsible for the disease. Despite several hypotheses proposed in recent years, the main hypothesis currently accepted focuses on irregular cell-cell adhesion that promotes myocyte death and subsequent replacement by fibro-fatty tissue. Concretely, this degenerative theory focuses on desmosomal mutations that inhibit Wnt signalling and, thereby, modulate pathological gene expression, promote cardiac myocytes apoptosis and mediate expression of a fibro-adipogenic phenotype. ${ }^{22}$ Desmosomal proteins (particularly plakoglobin (PG)) play a key role both as structural proteins and as nuclear signalling molecules, ${ }^{23}$ PG being a major mediator of adipogenesis. Thus, the pathogenesis of ARVC involves altered cell biomechanical behaviour and altered signalling that lead to cardiac myocytes injury and death. ${ }^{24}$

ARVC is frequently a familial disease, ${ }^{12}$ and recent studies conclude a familial affectation in up to $50 \%$ of cases, usually with an autosomal dominant pattern of inheritance, incomplete and age-related 
penetrance $^{25}$ and polymorphic phenotypic expression. ${ }^{26} \quad 27$ Autosomal recessive forms of ARVC have been also reported although they are less frequent and linked to mutations in different genes. ${ }^{28-30}$ As the overall rate of mutation discovery in ARVC is approximately 60\%-65\%, genetic testing has been incorporated in the revised TFC, serving as a critical tool to aid in diagnostic confirmation. Genetic testing allows cascade screening of relatives of a positive index case, identifying other genetic carriers who may be at risk of developing the disease and suffer SCD. ${ }^{25} 2631$ Familial genetic testing of sudden unexpected death victims with negative autopsy (SUDNA) identified ARVC-linked pathogenic mutations in $5 \%-10 \%$ of cases, ${ }^{32}$ and recent studies in SUDNA samples showed that approximately $25 \%$ of patients carried a mutation in the PKP2 gene. ${ }^{33}$ However, it still remains to be clarified whether definitive risk stratification can be based on mutation-phenotype relationship in the ARVC population. Even if genetic variation is identified in desmosomal genes, it does not indicate that the patient is going to be affected because of the variable penetrance. $^{34}$

\section{DISEASE-RELATED GENES}

Three different structures are involved in cell-cell adhesion in the myocardium: desmosomes, adherens junctions (zonula adherens/fasciae adherens) and gap junctions. Although genetic modifications of any of these three structures could theoretically induce the disease, only mutations in genes encoding desmosomal proteins have been associated with ARVC. So far, more than 800 genetic variants have been identified in 12 genes, but only around 300 have been classified as damaging, ${ }^{35}$ responsible for around $60 \%-65 \%$ of all ARVC cases. The 12 ARVC-related genes encode five desmosomal proteins (desmoplakin -DSP-, plakophilin-2 -PKP2-, desmoglein-2 -DSG2-, desmocollin-2 -DSC2- and PG -JUP-), and seven non-desmosomal proteins (desmin -DES-, transmembrane protein 43 -TMEM43-, transforming growth factor $\beta-3$-TGFB3-, lamin A/C -LMNA-, titin TTN-, phospholamban -PLN- and $\alpha$ T-catenin -CTNNA3-) (table 1). In 2001, a mutation in the cardiac ryanodine receptor, encoded by the ryanodine gene $(R y R 2)$ was identified in a patient affected by ARVC; ${ }^{36}$ however, this case has been recently classified as an ARVC phenocopy. ${ }^{37}$ To date, the majority of pathogenic mutations have been identified in genes coding for desmosomal proteins, with only the PKP2 gene being responsible for approximately $35 \%-40 \%$ of cases. Mutations in the genes DSP, DSG2 and DSC2 are responsible for nearly $15 \%-20 \%$ of ARVC cases. ${ }^{38-40}$

\section{Desmosomal genes}

Desmosomes are complex multiprotein structures of the cell membrane that provide structural and functional integrity to adjacent cells in different tissues, such as myocardium. Desmosome configuration includes adhesion molecules of the cadherin family (DSG and DSC) and proteins of the plakin and catenin families (desmoplakin, plakophilin and PG) which link intermediate filaments of the cytoskeleton to the desmosomal cadherins (figure 1).

\section{Plakophilin-2}

The most prevalent form of ARVC (type 9) is caused by mutations in the PKP2 gene (ENSG00000057294), which encode plakophilin-2 protein (PKP2, ENSP00000070846), an essential armadillo repeat protein located in the outer dense plaque of cardiac desmosomes that interacts with multiple other cell adhesion proteins ${ }^{41}$ (figure 2). Gerull et $a l^{42}$ suggested that absence and/or alteration of PKP2 structure in the cardiac desmosomes impair myocytes interactions among myocytes, inducing myocardium disruption, particularly in response to mechanical stress. Therefore, this may be a plausible explanation as to why exercise is a main inductor of ventricular tachyarrhythmias and SCD.

To date, more than 150 pathogenic mutations in PKP2 have been identified making it the main gene responsible for the disease (it represents around 35\%-40\% of total ARVC cases). The most prevalent variations in the PKP2 gene correspond to small deletion/insertion with frameshift pattern (40\%), ${ }^{35}$ followed by nonsense mutation in $25 \%$ of cases, missense variations in $20 \%$ and pathogenic splice site variations in $15 \%$. Most of the ARVC-linked pathogenic mutations identified in the PKP2 gene have an autosomal dominant pattern of inheritance (haploinsuffiency mechanism) although a recessive form was also described in $2006 .{ }^{30}$ In this last study, genetic screening identified a novel homozygous 7-base-pair deletion in the PKP2 gene, which was predicted to be translationally silent.

As mentioned above, genetic analysis of all ARVC-known genes by conventional Sanger resequencing identifies one genetic mutation in around $60 \%-65 \%$ of ARVC cases. Although the remaining cases may be secondary to pathogenic mutations within undiscovered genes, an alternative possibility is the presence of copy number variants (CNV): large deletions/insertions in known genes

Table 1 Genes associated with ARVC

\begin{tabular}{|c|c|c|c|c|c|}
\hline Gene & Locus & MIM & Gene ID & Protein & Inheritance \\
\hline CTNNA3 & $10 \mathrm{q} 21.3$ & 607667 & 29119 & $\alpha \mathrm{T}$-catenin & $A D$ \\
\hline DES & $2 q 35$ & 125660 & 1674 & Desmin & $A D$ \\
\hline$D S C 2$ & $18 q 21$ & 125645 & 1824 & Desmocollin-2 & $A D$ \\
\hline DSG2 & $18 q 12.1$ & 125671 & 1829 & Desmoglein-2 & $A D / A R$ \\
\hline$D S P$ & $6 p 24$ & 125647 & 1832 & Desmoplakin & $A D / A R$ \\
\hline JUP & $17 q 21$ & 173325 & 3728 & Junction plakoglobin & AD/AR \\
\hline LMNA & $1 \mathrm{q} 22$ & 150330 & 4000 & Lamin $A / C$ & $A D$ \\
\hline PKP2 & $12 \mathrm{p} 11$ & 609040 & 5318 & Plakophilin-2 & $A D / A R$ \\
\hline PLN & $6 q 22.1$ & 172405 & 5350 & Phospholamban & $A D$ \\
\hline TGFB3 & $14 q 24.3$ & 190230 & 7043 & Transforming growth factor $\beta 3$ & $A D$ \\
\hline TMEM43 & $3 p 25.1$ & 612048 & 79188 & Transmembrane protein 43 & $A D$ \\
\hline TTN & $2 q 31.2$ & 188840 & 7273 & Titin & $A D$ \\
\hline
\end{tabular}

$A D$, autosomal dominant; $A R$, autosomal recessive; ARVC, arrhythmogenic right ventricular cardiomyopathy; MIM, Mendelian Inheritance in Man. 
Figure 1 Diagram of desmosomal proteins related to arrhythmogenic right ventricular cardiomyopathy. DSC2, desmocollin-2; DSG2, desmoglein-2; DSP, desmoplakin; IF, intermediate filaments; PG, plakoglobin; PKP2, plakophilin-2; PM, plasmatic membrane.

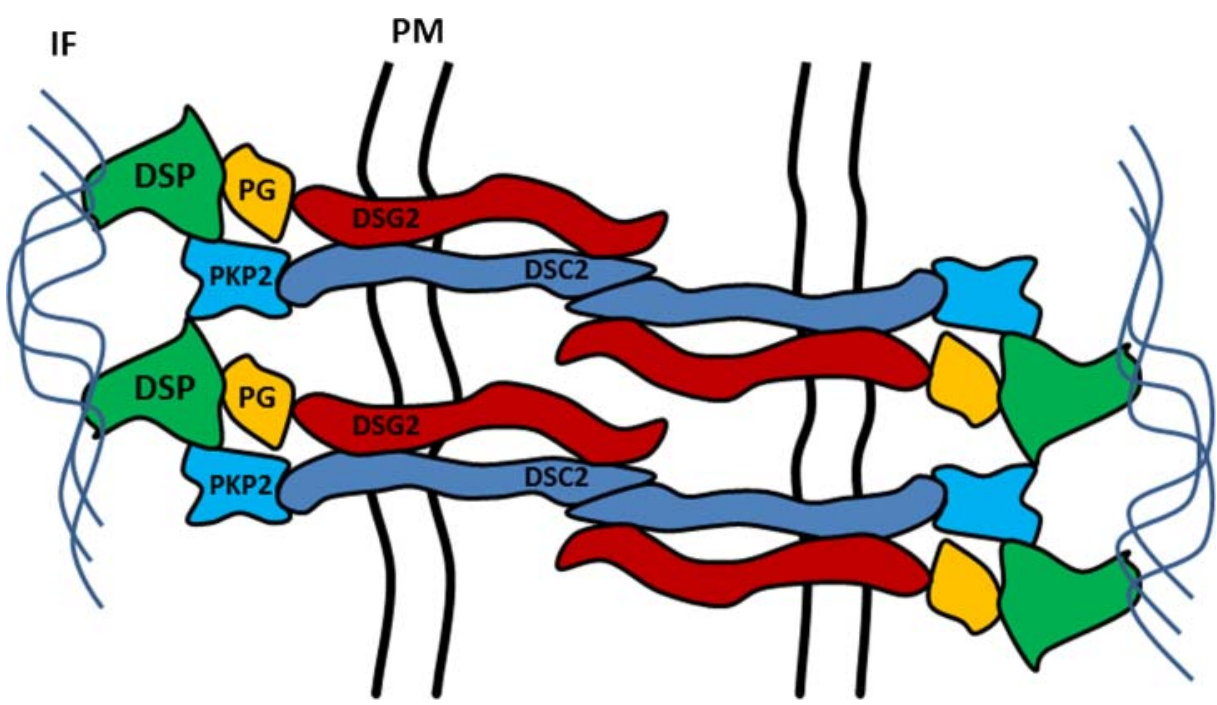

that are not detected by conventional genetic testing methods (Sanger sequencing). In 2010, Christensen reported a Danish cohort in which PKP2 large genomic insertions and deletions were excluded in all patients after multiplex ligation-dependent probe amplification. ${ }^{40}$ Recently, Roberts et $a l^{43}$ published two cases that developed ARVC due to large genomic PKP2 deletions, to date, the only CNVs study in ARVC cases. Thus, we strongly support that clinical genetic testing in ARVC cases should include screening for $\mathrm{CNV}$ when conventional sequencing analysis does not reveal pathogenic mutations after conventional Sanger resequencing of all ARVC-related genes.

\section{Desmocollin-2}

The desmosomal cadherins proteins, such as DSC and DSG, are the major constituents of the desmosomal plaque. Both proteins are type I integral membrane glycoproteins with four conserved extracellular subdomains, variable extracellular anchor domain, a single transmembrane domain, an intracellular anchor domain, and additional cytoplasmatic subdomains (figure 2). Both proteins participate in calcium-dependent cell adhesion, regulation of tissue morphogenesis and intracellular signalling processes. ${ }^{44}$ The DSC gene contains 17 exons ranging in size from 46 to $258 \mathrm{bp}$ and spans more than $32 \mathrm{~kb}$ of DNA. Exon 16 is alternatively spliced, giving rise to the $\alpha$ and $\beta$ forms of the protein. So, it encodes two products derived from alternatively spliced transcripts from single genes (DSC1 and DSC2). The human DSC2 gene (ENSG00000134755) encodes the most widely distributed form of DSC proteins, DSC2 (ENSP00000280904). ${ }^{45}$

In 2006, Heuser et al published the first DSC2 gene mutations in humans affected by ARVC (type 11). They also established that physiological levels of the DSC2 protein are essential for cardiac desmosome formation, early cardiac morphogenesis and cardiac function. ${ }^{46}$ To date, less than 50 pathogenic mutations on DSC2 gene have been linked to ARVC, and $50 \%$ of them are missense mutations, while the rest correspond to nonsense mutations and small deletions/insertions that induce frameshift variations. In addition, four splice site pathogenic variations have been identified in the DSC2 gene in ARVC cases that fulfil TFC diagnostic criteria. ${ }^{35}$

\section{Desmoglein-2}

DSGs are desmosomal cadherins and, together with DSCs, form the two essential transmembrane components of the desmosome (figure 2). Each member of the DSG protein family (DSG type 1-4) has four extracellular cadherin domains and a transmembrane domain. ${ }^{44}$ DSG2 (ENSP00000261590) is the only isoform expressed in cardiac myocytes.

In 2006, two reports linked pathogenic mutations in the DSG2 gene (ENSG00000046604) to ARVC. ${ }^{47}{ }^{48}$ Since then, more than 50 pathogenic variants have been associated with
Figure 2 Structural characteristics of main desmosomal proteins responsible for arrhythmogenic right ventricular cardiomyopathy. C, C-terminus; DSC2, desmocollin-2; DSG2, desmoglein-2; DSP, desmoplakin; JUP, plakoglobin; N, N-terminus; PKP2, plakophilin-2.
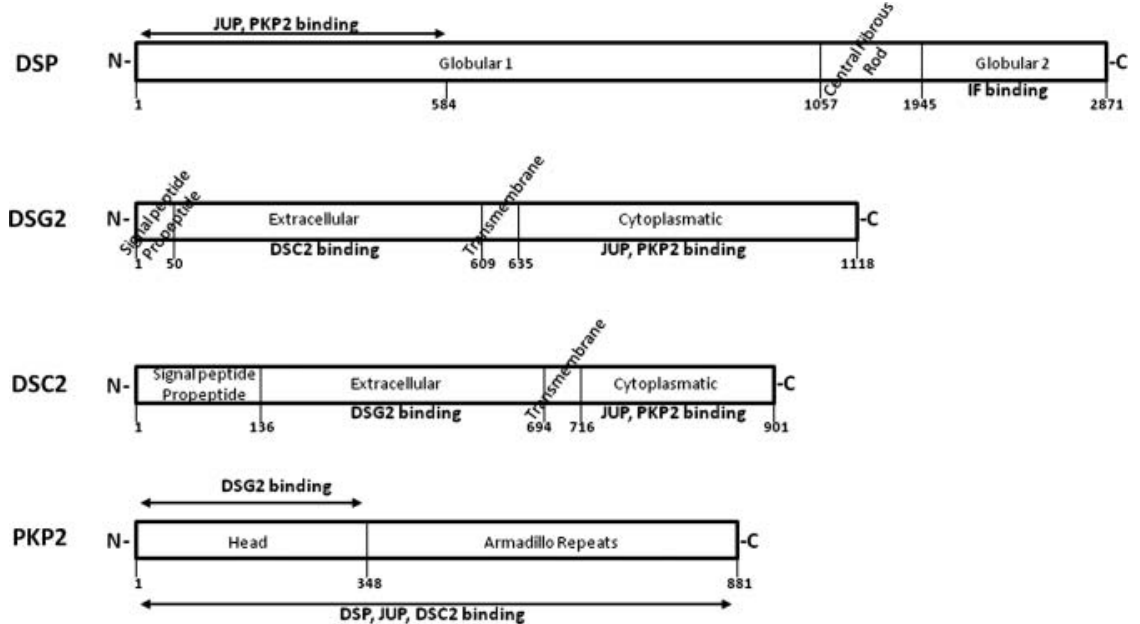
ARVC (type 10). Of them, around 60\% are missense mutations, $20 \%$ correspond to small insertions/deletions and other $20 \%$ to splice site changes. ${ }^{35}$ Despite the fact that most of the identified mutations have a dominant patter of inheritance, a recessive pattern has been suggested also in ARVC patients, ${ }^{48}$ although hitherto, no conclusive relation has been reported.

\section{Desmoplakin}

Desmoplakin is the most abundant protein of the desmosomes, encoded by the DSP gene (ENSG00000096696). Desmoplakin has two isoforms produced by alternative splicing: the longest desmoplakin I isoform (ENSP00000369129) and the shorter desmoplakin II (ENSP00000396591). Desmoplakin isoform I has been reported to be a force constituent of desmosomes and the major isoform present in cardiac tissue, although expression of isoform II (DSPII) occurs in different heart compartments $^{49}$ (figure 2).

The first report of a pathogenic variation in the DSP gene linked to ARVC was published in 2002. ${ }^{50}$ Some years later, Yang et al performed in vitro and in vivo analyses of the mutant DSP proteins, showing interruption of DSP-DES interaction at intercalated discs and marked ultrastructural changes. Thus, the results suggested that DSP expression in cardiomyocytes is crucial for maintaining cardiac tissue integrity, and that DSP protein abnormalities lead to cardiomyocyte death, changes in lipid metabolism and defects in cardiac development. ${ }^{51}$

Almost 100 pathogenic variations in the DSP gene have been linked to ARVC (type 8). In all, 40\% are missense variations, $30 \%$ nonsense variations, and the rest are small insertions/deletions and splice sites. ${ }^{35}$ Heterozygous DSP mutations lead to a wide ARVC phenotypic heterogeneity, including forms associated with dermatological phenotypes. The DSP gene was also implicated in Carvajal syndrome, an autosomal recessive cardiocutaneous form of ARVC that was described as a variant of Naxos syndrome (see below, Plakoglobin section) in which the cardiomyopathy presents a more pronounced LV involvement, palmoplantar keratoderma and woolly hair. ${ }^{29} 52$ Another DSP recessive mutation was identified in a large Arab family with a high rate of consanguinity causing ARVC, woolly hair and pemphigus-like skin disorder. ${ }^{53} \mathrm{~A}$ debate still exists about whether the cardiac phenotype in the Arab family appears to be classic ARVC or modified Carvajal syndrome. Finally, since 2010, three studies has reported single heterozygous DSP missense mutations in unrelated patients leading to combined phenotypes resembling Naxos-Carvajal syndrome. ${ }^{54-56}$ All these mutations are localised in a small DSP region (from 564 to 597 aminoacids), suggesting a key role for this DSP region involved in the interactions with plakophilin or PG leading to combined Naxos-Carvajal phenotypes.

\section{Plakoglobin}

PG is a major component protein of cell adhesion junctions, and the only constituent common to submembranous plaques of both desmosomes and intermediate junctions. PG also forms distinct complexes with cadherins and desmosomal cadherins, being a member of the catenin family since it contains a distinct repeating aminoacid motif (called armadillo repeat). Concretely, PG plays a crucial role in linking the desmosomal cadherins, DSG and DSC, to the cytoskeleton via DP (figure 2). The PG protein (ENSP00000311113) is codified by JUP (ENSG00000173801) and implicated in ARVC (type 12). ${ }^{28}$

The first genetic mutation associated with ARVC was a homozygous deletion in the JUP gene, with an autosomal recessive pattern of inheritance. ${ }^{28}$ The disease was originally identified in patients on the Greek island of Naxos and hence it is referred to as 'Naxos disease'. ${ }^{57}$ It is characterised by non-epidermolytic palmoplantar keratoderma, woolly hair and right sided cardiomyopathy. Homozygotes for Naxos disease usually have no cardiac symptoms during childhood but penetrance is $100 \%$ during adolescence. Patients present with symptomatic arrhythmias, ECG alterations, structural damage of RV in all cases and $\mathrm{LV}$ involvement in $35 \%$ of cases. ${ }^{58} 59$

To date, less than 20 pathogenic mutations has been identified in JUP, and 50\% correspond to missense mutations. All other mutations are insertions/deletions and one splice site. Of all mutations, only five correspond to homozygous variations. ${ }^{35}$

\section{Non-desmosomal genes}

While mutations in desmosomal genes are the main cause of ARVC, mutations in six other genes have been also associated with the disease (table 1). These genes encode for intermediate filaments, and regulatory factors, among other proteins. Although there are only a few studies describing the prevalence of pathogenic mutations identified in all these proteins in ARVC, all together they are responsible of approximately 10\% of ARVC cases. Despite their low prevalence, we consider that it is important to study them in order to perform a comprehensive genetic testing.

\section{Desmin}

DES is the main intermediate filament protein (ENSP00000363071) in mature skeletal and heart muscle cells, encoded by the DES gene (ENSG00000175084). DES gene contains nine exons and spans about $8.4 \mathrm{~kb}$. Intronic sequences contain four AluI repetitive elements, and the promoter region is $G$ rich. It forms a scaffold around the Z-disk and links whole contractile structure with subsarcolemmal cytoskeleton, intercalated disk, nucleus and other components of the cytoplasm. DES-related myopathy is a clinically heterogeneous group of disorders encompassing myopathies, cardiomyopathies, conduction disease and combinations of these disorders. ${ }^{60}$

Even though several mutations related to myopathies have been identified in the DES gene, the first study on mutations in ARVC patients was reported in $2009 .^{61}$ Later, Otten et al ${ }^{62}$ reported that a DES mutation affects the localisation of DSP and PKP2 proteins at the intercalated disk. So far, only less than 10 pathogenic variants linked to ARVC have been identified in DES gene. Overall, $90 \%$ of them are missense variations and only a small number of mutations are deletions. ${ }^{35}$ Thus, in the absence of skeletal muscle involvement suggestive of a desminopathy, the probability of ARVC-related mutations in the DES gene is very low. ${ }^{63}$

\section{Transforming growth factor $\beta-3$}

TGFB3 (ENSP00000238682) is a member of the TGF family, pleiotropic and multifunctional peptides that exerts diverse effects on different cell types. Three structurally similar isoforms of TGF $\beta$ (TGF $\beta 1,2$ and 3), encoded by three distinct genes, have been identified in mammalian species. The TGF $\beta 3$ gene (ENSG00000119699) encodes TGFß3 protein, a cytokine that stimulates fibrosis, and modulates cell adhesion and expression of desmosomal genes. ${ }^{64}$

The first association between ARVC (type 1) and this gene was reported in $2005 .^{65}$ This study identified two mutations in the untranslated region zone (one in $5^{\prime}$ and the other one in $3^{\prime}$ ) in two affected families. Desmosomal genes were not analysed in any patient of this series. Recent findings suggest that the elevated TGF $\beta$ signalling is associated with the pathogenesis of 
JUP-related ARVC. ${ }^{66} 67$ To date, these are the only two pathogenic variations in TGF $\beta 3$ reported in ARVC patients. Controversy still remains about a clear relation between this genes and ARVC.

\section{Transmembrane protein 43}

The gene TMEM43 (ENSG00000170876) contains 12 exons and spans $18.7 \mathrm{~kb}$. It encodes the protein transmembrane protein 43 (TMEM43, ENSP00000303992). The exact function of this gene is still unknown. This gene has been suggested to have a role in an adipogenic pathway because it has a peroxisome proliferator response element (PPAR $\chi$, an adipogenic transcription factor). Dysregulation of this adipogenic pathway may explain the myocardial fibro-fatty replacement in ARVC patients (type 5). ${ }^{68}$

Only two pathogenic mutations had been described previously, but a recent report has described three additional new pathogenic mutations among 143 UK ARVC probands tested negative for mutations in desmosomal genes. ${ }^{69}$ Detailed genotype-phenotype studies of families with TMEM43 mutations have shown a marked influence of male sex on an earlier and more severe clinical presentation. ${ }^{20}$

\section{Lamin A/C}

The gene LMNA (ENSG00000160789) spans approximately $24 \mathrm{~kb}$ and contains 12 exons. Alternative splicing within exon 10 gives rise to two different mRNAs that code for prelamin A and lamin C. Thus, this gene encodes lamin A (ENSP00000357283) and lamin C (ENSP00000357284), by alternative splicing. Both of them belong to the family of type $\mathrm{V}$ intermediate filaments that take part in the constitution of the nuclear lamina, a complex of proteins below the inner part of the nuclear membrane. ${ }^{70}$ Both lamins $\mathrm{A}$ and $\mathrm{C}$ contain a 360 -residue $\alpha$-helical domain with homology to a corresponding $\alpha$-helical rod domain that is the structural hallmark of all intermediate filament proteins.

Genetic alterations in LMNA are associated with a heterogeneous group of disorders commonly named 'laminopathies,' including cardiac disorders, ${ }^{71}$ although no relation between the LMNA gene and ARVC had been reported until 2012 when Quarta et $a l^{72}$ performed a genetic study in a cohort of 108 ARVC patients, and identified mutations in the LMNA gene in the affected individuals. Also in 2012, a study focused on a cohort of SCD samples due to suspected cardiomyopathy has identified a missense mutation in the LMNA gene, ${ }^{73}$ supporting the addition of this gene to genetic testing in patients with suspected/confirmed ARVC diagnosis.

Titin

The cardiac sarcomere contains actin-based thin and myosinbased thick filaments, and the giant protein TTN, ENSP00000343764 (also named connectin). Between its thin and thick filament binding domains TTN contains a large segment that behaves as a molecular spring that extends during sarcomere stretch. TTN protein is encoded by the gene TTN (ENSG00000155657) in 363 exons and it is involved in numerous cellular processes including maintaining sarcomere structure and force-dependent signalling. ${ }^{74}$

Despite being the candidate gene responsible for structural cardiac diseases due to its key role in mechanical movement, no reports associated the TTN gene with ARVC until 2011, when Taylor $e t a l^{75}$ reported for the first time eight missense mutations in the TTN gene in ARVC patients. We think that this number will increase progressively if TTN is analysed in ARVC patients as it has occurred in a cohort of patients affected by DCM. $^{76}$ To our knowledge, TTN genetic testing it is not routinely being performed in ARVC cases due to the technical difficulties to analyse such a long gene.

\section{Phospholamban}

The gene PLN (ENSG00000198523) encodes the protein PLN (ENSP00000350132), a small phosphoprotein closely associated with the cardiac sarcoplasmic reticulum. It is a regulator of the sarcoplasmic reticulum $\mathrm{Ca}^{2+}$ (SERCA2a) pump in cardiac muscle and therefore important for maintaining $\mathrm{Ca}^{2+}$ homeostasis. ${ }^{77}$ Consequently, the PLN protein is one of the major determinants of cardiac contractility and relaxation. ${ }^{78}$

To date, several PLN mutations have been identified in dilated cardiomyopathy (DCM) patients, but recently, a PLN pathogenic mutation was published in a Dutch ARVC family, linking for the first time ARVC with mutations in the PLN gene. ${ }^{79}$ Curiously enough, this study showed that carriers of p.R14del mutation in the PLN gene presented with two different phenotypes: DCM or ARVC. This mutation has previously been associated with a low voltage in the ECG. ${ }^{80}$ Therefore, the authors suggested that PLN_R14del is responsible for 'arrhythmogenic cardiomyopathy' an entity encompassing ARVC, including leftdominant arrhythmogenic cardiomyopathy, and arrhythmogenic forms of DCM. In fact, the genetic overlap between ARVC and DCM has been shown also in other ARVC-related genes identified to date. ${ }^{72} 8182$

\section{$\alpha \mathrm{T}$-catenin}

The CTNNA3 gene (ENSG00000183230) encodes the protein $\alpha \mathrm{T}$-catenin (catenin cadherin-associated protein $\alpha 3$ (CTNNA3), ENSP00000389714). $\alpha$-Catenins are cytoplasmic molecules thought to be indispensable for dynamic maintenance of tissue morphogenesis by integrating in the cadherin-catenin complex. ${ }^{83}$ There are three $\alpha$-catenin subtypes in mammals: the ubiquitously expressed $\alpha \mathrm{E}$-catenin, the neural $\alpha \mathrm{N}$-catenin and $\alpha \mathrm{T}$-catenin. ${ }^{84}$ $\alpha \mathrm{T}$-catenin protein is located within the area composite of intercalated disks of cardiomyocytes and in peritubular myoid cells of the testis. The gene is located in a common fragile site epigenetically regulated, transcribed through multiple promoters, and generating a variety of alternate transcripts. ${ }^{85}$ It colocalises with CTNNA1 (catenin cadherin-associated protein $\alpha 1$ ) and CTNNA2 (catenin cadherin-associated protein $\alpha$ 2) proteins. ${ }^{86}$ In addition, it also interacts with the protein CTNNB1 (catenin cadherin-associated protein $\beta 1){ }^{87}$

In 2003, the gene CTNNA3 was assessed in order to identify a potential relation to DCM but no DCM-linked CTNNA3 mutations were identified. ${ }^{88}$ Recently, Li et $a l^{89}$ developed an animal model that demonstrates how perturbation in $\alpha \mathrm{T}$-catenin can affect both the PKP2 and Cx43 proteins and thereby highlights the importance of understanding the crosstalk between the junctional proteins of the intercalar disk and its implications for DCM, suggesting the potential role of this gene in ARVC. Recently, two missense mutations have been identified in two unrelated patients of an ARVC cohort. ${ }^{90}$ This report relates for the first time the protein $\alpha \mathrm{T}$-catenin to ARVC.

\section{CANDIDATE GENES Locus identified}

Genetic studies have mapped two different loci for ARVC (10p12-p14 and 14q12-q22) although the gene responsible for the pathology is still unknown. A linkage analysis identified a novel locus (10p12-p14) in ARVC cases but again, no mutation has been identified in known genes. The authors also studied 
the possible involvement of the tyrosine phosphatase-like gene (PTPLA) that encodes the protein PTPLA but only a polymorphism was identified. ${ }^{91}$ The second locus was suggested by a study focusing on three families, which found a genetic linkage in the proximal portion of $14 \mathrm{q}(14 \mathrm{q} 12-\mathrm{q} 22)$. These data indicated that a novel gene causing familial ARVC could be located in the long arm of chromosome $14^{92}$ but it is unknown so far.

\section{Suspicious genes analysed}

Currently, 12 genes have been linked to ARVC but in up to $35 \%-40 \%$ of patients no causal mutation is identified in the candidate genes. New ARVC-related genes are being investigated, and those encoding proteins related to desmosomes, adherent junctions and gap junctions are considered to be possible candidate genes. A genome-wide study focused on a spontaneous canine model of ARVC identified an 8-bp deletion in the $3^{\prime}$ untranslated region of the Striatin gene (STRN), which encodes the striatin protein (STRN), suggesting this gene as a candidate gene for ARVC in humans. ${ }^{93}$ However, further studies such as segregation in humans and in vitro analysis should be performed to determine the possible role of this gene in the human pathogenesis of ARVC. Another study on a cohort of ARVC human samples analysed three genes not previously associated with the disease: $\beta$-catenin (CTNNB1), $\alpha$-T-catenin (CTNNA3) and PERP $(P E R P)$, which encode structural proteins of importance for cellular adhesion. No mutations were identified in any of three genes analysed despite their involvement in formation and maintenance of the intercalated disk. ${ }^{94}$ However, a recent study on a cohort of ARVC patients have identified two mutations in the CTNNA3 gene, suggesting a low frequency of mutations in this gene but recommend systematic genetic screening for this gene in ARVC families. ${ }^{90}$

In addition, Friedrich et al reported a new gain-of-function variant in the human ISL1 gene; this study identified the variant in one DCM affected family and in one hypertrophic cardiomyopathy (HCM) patient. It suggests that this gene could potentially lead to greater activation of downstream targets involved in cardiac abnormalities, such as ARVC. ${ }^{95}$ Furthermore, the gene ISL1 is directly regulated by $\beta$-catenin (CTNNB1 gene), another ARVC candidate gene.

Recent studies have shown several limitations in order to perform a classification system for cardiomyopathies mainly due to overlapping clinical features. The distinction of HCM, DCM and ARVC as separate clinical entities has important implications for clinical practice, guiding both diagnostics and treatment. ${ }^{9697}$ Focus on genetics and pathogenic mutations in the same gene can result in phenotypic heterogeneity. For example, so far, mutations in the DES, LMNA, TTN and PLN genes, both in DCM and ARVC patients have been identified. Even genetic variations in TTN and PLN have been identified in HCM cases. All these facts suggest that the term desmosomal disease can no longer be synonymous with ARVC. Recent studies support the concept of 'arrhythmogenic cardiomyopathy' as an entity encompassing arrhythmogenic forms of DCM and ARVC. ${ }^{23} 98$ Although it is known that disease-causal gene alterations in desmosomal proteins show definite overlaps between DCM and ARVC, the underlying mechanisms responsible for these differences are not yet understood. Therefore, it has been suggested that environmental factors and interaction between genetic variations as regulatory factors that determine the pathogenic variations lead to ARVC phenotypes.

Our group analysed a cohort of ARVC patients with no mutation in any of disease-related genes. In our cohort, seven genes were assessed-ACTC1 (actin $\alpha$ cardiac muscle 1), CDHN (cadherin 2 type 1 or N-cadherin), CTNNA1 (catenin $\alpha 1$ ), Cx43 or GJA1 (gap junction protein $\alpha 1$ ), MVCL (metavinculin), MYL2 (myosin light chain 2) and MYL3 (myosin light chain 3)-, all related to desmosome structure but no mutation was identified in any of them. ${ }^{99}$ Both studies were performed in a reduced number of ARVC patients suggesting the need to assess all these genes in large cohorts and focus future research into the pathogenesis of ARVC on other components of cardiomyocyte adhesion.

\section{HIGH-THROUGHPUT TECHNOLOGIES}

In the last 10 years, advances in genetics allow us to rapidly sequence human genomes and generate genetic data for a relatively small cost, reducing the issues of possible human error, and opening up numerous opportunities for translation into the clinical area in near future. ${ }^{100}$ The new technology named Next Generation Sequencing (NGS) allows a massively parallel resequencing in a short period of time, progressively reducing the costs of sequencing itself and the time spent on data analysis and computer storage requirements. Although each identified genetic variant needs to be confirmed by traditional Sanger sequencing mainly due to the poor coverage of gene promoters and repetitive or GC-rich sequences, NGS is being progressively incorporated to clinical practice. It will help to identify genetic defects in families affected by cardiac pathologies in which no pathogenic mutation has been found to date, improving current diagnosis, prevention and treatment, as suggested by Polychronakos and Seng recently. ${ }^{101}$ However, the use of NGS to identify gene mutations could face huge challenges, in particular, in small families and sporadic cases, to discern the disease causing variants from those that by chance alone are carried by the affected persons. ${ }^{63}$

Despite all these controversies, some recent studies highlight the high value of integrating genomic approaches in the effective evaluation of patients affected by heterogeneous diseases, rapidly identifying disease-causative variants in known genes, and also revealing novel candidate disease genes. ${ }^{102-104}$ Therefore, a recent publication about a family affected by ARVC identified the first pathogenic mutation in the gene DES by whole exome sequencing. ${ }^{105}$

Another technology, MassARRAY iPLEX Gold PlatformSEQUENOM-has been used to identify known common pathogenic mutations in patients affected by long QT syndrome, ${ }^{106}$ and HCM. ${ }^{107}$ Our group has used this technology to identify known pathogenic mutations in ARVC postmortem samples, especially when the DNA quality only enables the identification of limited number of point mutations (Alcalde $\mathrm{M}$ et al, unpublished data).

\section{GENETIC RISK STRATIFICATION}

Incomplete penetrance and variable expressivity are hallmarks of ARVC, making it difficult for clinicians to evaluate the risk of developing the disease. Several clinical features have been proposed to indicate high risk of ARVC patients, such as SCD family history, syncope, severe RV dysfunction and LV involvement, among others. ${ }^{108}$ In recent years, genetics has played a key role in studying phenotype variations although these variations are independent of the gene affected, even among family members sharing the same gene variant, suggesting that additional genetic and/or environmental modifiers can influence the disease phenotype. ${ }^{27}$

As mentioned above, more than 300 pathogenic mutations have been identified in the 12 ARVC-related genes. In addition, more than 250 are classified as of unknown significance, and 
more than 900 are considered not to have pathogenic effect. ${ }^{35}$ However, a modulator role of these non-pathogenic variations in the phenotype remains not fully understood. All these genetic variations have been identified mainly in desmosomal genes, PKP2 being the most prevalent gene. ${ }^{109}$ The variable expressivity and incomplete penetrance in ARVC patients could be explained by the type of mutation in the causal gene and/or the presence of multiple genetic variants in modifier genes. To elucidate the potential role of a genetic variation in ARVC, in recent years, artificial systems using transfected cell cultures and transgenic mice ${ }^{110}$ have been performed. Recently, keratinocyte cultures have been used because of their expression in all cardiac-specific isoforms of desmosomal proteins. ${ }^{111} 112$

A genetic compilation has been published recently by Kapplinger et $a l^{39}$ reporting that most mutations in the PKP2 gene correspond to 'radical' genetic variations, a term that included inframe, frameshift indels, splice junction and nonsense mutations. However, most genetic variations in DSG2, DSC2 and DSP genes are missense mutations. While radical mutations are considered highly pathogenic, little is known in ARVC-related genes about the difference between missense mutations and 'background' genetic variations, common genetic variations in population. For example, and as mentioned before, recently a potential pathogenic missense mutation in the TMEM43 gene has been identified in a study of a limited cohort from UK and Canada. The genetic variation has also been found in control population but at a low frequency. Then the authors have suggested that the missense variation is a 'pathogenic founder mutation'69 but further studies should be performed to elucidate the role of this novel variation in ARVC patients.

In order to discriminate genetic background and real pathogenic variants is crucial to perform an interpretation in genotype-phenotype correlation, focus in familial cosegregation. The authors suggested that each missense mutation should be assessed with caution, taking into account mutation localisation, gene, evolutionary conservation of the aminoacid residue, and race and ethnicity of patient (to exclude founder mutations). In addition, minor allele frequency (MAF) in population helps to distinguish pathogenic variants from common genetic variations (MAF $>1 \%$ ), and in silico databases predict the possible pathogenic role of a new variation.

Referring to causal genes, the PKP2 gene is the main gene responsible for ARVC, as mentioned above. In addition, it has been also recently published that PKP2 mutations were most frequently identified to be causal for ARVC, ${ }^{113}$ essentially because most of these mutations are 'radical' genetic variations, considered highly pathogenic. ${ }^{39}$ The second gene responsible for the pathology is DSG2. Mutations in the DSG2 gene were associated with more frequent LV involvement. ${ }^{114} 115$ The other two ARVC-associated genes are DSP and DSC2. In 2005, mutations in C-terminus of DSP protein have been related to biventricular phenotype. ${ }^{116}$

In recent years, researchers have explored compound heterozygosity in a single gene, double mutations in more than one desmosomal gene (digenic inheritance) and phenotype modification due to polymorphism, hypothesising that ARVC might require multiple genetic hits in the cell adhesion complex to cause the phenotype, ${ }^{34} 117118$ but no clear explanation has been reported for the wide variability and penetrance in families affected by ARVC. In 2009 , Bhuiyan et $a l^{119}$ reported that biallelic or digenic DSC2 and/ or DSG2 gene mutations are frequently identified in ARVC patients, suggesting that a single mutation is less likely to cause the pathology. Accordingly, it has also been reported that carriers of various genetic mutations exhibit a higher probability to develop ARVC phenotype as compared with patients with a single mutation. ${ }^{25} 118$ Fressart et $a l^{54}$ also reported that various mutations identified in the same patient were associated with higher frequency of SCD. Christensen $e t a l^{40}$ reported that a substantial proportion of ARVC affected patients carried more than one mutation in any of desmosomal gene, but the phenotype associated with the double mutation carrier status was variable. However, other studies reported a gene dosage effect with patients carrying more than one mutation having a more severe phenotype. ${ }^{34} 120$ These studies were performed in small cohorts, which necessitates further investigations to corroborate all these results. Our group also reported possible severe clinical phenotypes in patients carrying more than one mutation, but no greater structural abnormalities were identified in any of them. In the same study, we also reported an apparently more benign phenotype in genetic carriers of polymorphism p.P336L in the PKP2 gene but the analysis should be interpreted with caution given the small sample size. ${ }^{121}$

Despite all these genetic data, current genotype-phenotype studies are too limited to establish a certain role of genetics in clinical practice. Up to now, the majority of data available on risk stratification and management strategies in patients with ARVC have relied on retrospective analyses in single centres and with rather small patient cohorts. In addition, it is well known that to perform a genetic testing in clinical practice also implies a genetic counselling, helpful adjunct in the diagnosis and management of the pathology. ${ }^{122}$ Therefore, because of complex interpretation of genetic results in phenotype, current international recommendations for clinical cardiomyopathies support the involvement and collaboration among cardiologist, geneticists and even psychologists to perform a genetic counselling prior and subsequent to genetic testing. ${ }^{123} 124$

\section{CONCLUSIONS}

In recent years, genetic analysis has been incorporated progressively into ARVC diagnosis. To date, several mutations in 12 genes have been related to the disease. However, around $35 \%-40 \%$ of the ARVC cases remain without a genetic cause identified. Thus, other unknown genes should be responsible for at least almost one part of these cases without genetic diagnosis. In addition to pathogenic point mutations, CNVs in these genes have been also related to the disease. In near future, new genetic technologies will allow faster, and less expensive, testing of more genes (previously related and new genes) and other genetic defects. Genetic testing is especially useful in families with at least one affected member who carries a pathogenic mutation identified because it allows establishing a presymptomatic diagnosis among relatives. However, even though crucial, genetic counselling in current clinical practice, on the basis of current genetic-phenotype knowledge, is speculative to establish an impact of genetics in clinical ARVC risk stratification.

Contributors All authors contributed to the acquisition of data. All authors contributed to drafting or revising the content and approved the final version.

Funding This work was supported by Centro Nacional de Investigaciones Cardiovasculares (CNIC-03-2008), Instituto de Salud Carlos III (FIS-PI11/01826),

'Fundació La Caixa' and RETICS (Red Cardiovascular Enfermedades. RETICS Cardiopatías Familiares y Congénitas. Instituto de Salud Carlos III).

Competing interests None.

Provenance and peer review Not commissioned; externally peer reviewed.

\section{REFERENCES}

1 Frank R, Fontaine G, Vedel J, Mialet G, Sol C, Guiraudon G, Grosgogeat Y. (electrocardiology of 4 cases of right ventricular dysplasia inducing arrhythmia). Arch Mal Coeur Vaiss 1978;71:963-72. 
2 Marcus Fl, Fontaine GH, Guiraudon G, Frank R, Laurenceau JL, Malergue C, Grosgogeat $Y$. Right ventricular dysplasia: a report of 24 adult cases. Circulation 1982;65:384-98.

3 Marcus Fl, Abidov A. Arrhythmogenic right ventricular cardiomyopathy 2012: diagnostic challenges and treatment. J Cardiovasc Electrophysiol 2012;23:1149-53.

4 Gallo P, d'Amati G, Pelliccia F. Pathologic evidence of extensive left ventricular involvement in arrhythmogenic right ventricular cardiomyopathy. Hum Pathol 1992;23:948-52.

5 Michalodimitrakis M, Papadomanolakis A, Stiakakis J, Kanaki K. Left side right ventricular cardiomyopathy. Med Sci Law 2002;42:313-17.

6 Lindstrom L, Nylander E, Larsson $H$, Wranne B. Left ventricular involvement in arrhythmogenic right ventricular cardiomyopathy-a scintigraphic and echocardiographic study. Clin Physiol Funct Imaging 2005;25:171-7.

7 Li CH, Lin YJ, Huang JL, Wu TJ, Cheng CC, Lin WS, Tuan TC, Chang SL, Lo LW, Hu YF, Chao TF, Chung FP, Tsai CF, Tsao HM, Chen SA. Long-term follow-up in patients with arrhythmogenic right ventricular cardiomyopathy. I Cardiovasc Electrophysiol 2012;23:750-6.

8 Battipaglia I, Scalone G, Macchione A, Pinnacchio G, Laurito M, Milo M, Pelargonio G, Bencardino G, Bellocci F, Pieroni M, Lanza GA, Crea F. Association of heart rate variability with arrhythmic events in patients with arrhythmogenic right ventricular cardiomyopathy/dysplasia. Circ J 2012;76:618-23.

9 McKenna WJ, Thiene G, Nava A, Fontaliran F, Blomstrom-Lundqvist C, Fontaine G, Camerini F. Diagnosis of arrhythmogenic right ventricular dysplasia/ cardiomyopathy. Task force of the working group myocardial and pericardial disease of the european society of cardiology and of the scientific council on cardiomyopathies of the international society and federation of cardiology. $\mathrm{Br}$ Heart J 1994;71:215-18.

10 Marcus FI, McKenna WJ, Sherrill D, Basso C, Bauce B, Bluemke DA, Calkins H, Corrado D, Cox MG, Daubert JP, Fontaine G, Gear K, Hauer R, Nava A, Picard MH, Protonotarios N, Saffitz JE, Sanborn DM, Steinberg JS, Tandri H, Thiene G, Towbin JA, Tsatsopoulou A, Wichter T, Zareba W. Diagnosis of arrhythmogenic right ventricular cardiomyopathy/dysplasia: Proposed modification of the task force criteria. Circulation 2010;121:1533-41.

11 Nava A, Martini B, Thiene G, Buja GF, Canciani B, Scognamiglio R, Miraglia G, Corrado D, Boffa GM, Daliento L. (Arrhythmogenic right ventricular dysplasia. Study of a selected population). G Ital Cardiol 1988:18:2-9.

12 Nava A, Thiene G, Canciani B, Scognamiglio R, Daliento L, Buja G, Martini B, Stritoni P, Fasoli G. Familial occurrence of right ventricular dysplasia: A study involving nine families. J Am Coll Cardiol 1988;12:1222-8.

13 Daliento L, Turrini P, Nava A, Rizzoli G, Angelini A, Buja G, Scognamiglio R, Thiene $\mathrm{G}$. Arrhythmogenic right ventricular cardiomyopathy in young versus adult patients: Similarities and differences. J Am Coll Cardiol 1995;25:655-64.

14 Wichter T, Schafers M, Rhodes CG, Borggrefe M, Lerch H, Lammertsma AA Hermansen F, Schober O, Breithardt G, Camici PG. Abnormalities of cardiac sympathetic innervation in arrhythmogenic right ventricular cardiomyopathy: quantitative assessment of presynaptic norepinephrine reuptake and postsynaptic beta-adrenergic receptor density with positron emission tomography. Circulation 2000;101:1552-8.

15 Bauce B, Frigo G, Marcus Fl, Basso C, Rampazzo A, Maddalena F, Corrado D, Winnicki M, Daliento L, Rigato I, Steriotis A, Mazzotti E, Thiene G, Nava A. Comparison of clinical features of arrhythmogenic right ventricular cardiomyopathy in men versus women. Am J Cardiol 2008;102:1252-7.

16 Thiene G, Nava A, Corrado D, Rossi L, Pennelli N. Right ventricular cardiomyopathy and sudden death in young people. N Engl J Med 1988;318:129-33.

17 Corrado D, Thiene G, Nava A, Rossi L, Pennelli N. Sudden death in young competitive athletes: clinicopathologic correlations in 22 cases. Am J Med 1990;89:588-96.

18 Schuler PK, Haegeli LM, Saguner AM, Wolber T, Tanner FC, Jenni R, Corti N, Luscher TF, Brunckhorst C, Duru F. Predictors of appropriate icd therapy in patients with arrhythmogenic right ventricular cardiomyopathy: long term experience of a tertiary care center. PloS one 2012;7:e39584.

19 Berul Cl, Van Hare GF, Kertesz NJ, Dubin AM, Cecchin F, Collins KK, Cannon BC, Alexander ME, Triedman JK, Walsh EP, Friedman RA. Results of a multicenter retrospective implantable cardioverter-defibrillator registry of pediatric and congenital heart disease patients. J Am Coll Cardiol 2008;51:1685-91.

20 Hodgkinson KA, Parfrey PS, Bassett AS, Kupprion C, Drenckhahn J, Norman MW, Thierfelder L, Stuckless SN, Dicks EL, McKenna WJ, Connors SP. The impact of implantable cardioverter-defibrillator therapy on survival in autosomal-dominant arrhythmogenic right ventricular cardiomyopathy (arvd5). J Am Coll Cardiol 2005:45:400-8

21 Corrado D, Basso C, Pilichou K, Thiene G. Molecular biology and clinical management of arrhythmogenic right ventricular cardiomyopathy/dysplasia. Heart 2011:97:530-9.

22 Zhurinsky J, Shtutman M, Ben-Ze'ev A. Plakoglobin and beta-catenin: protein interactions, regulation and biological roles. J Cell Sci 2000;113(Pt 18):3127-39.

23 Saffitz JE. The pathobiology of arrhythmogenic cardiomyopathy. Annu Rev Pathol 2011:6:299-321.

24 Saffitz JE, Asimaki A, Huang H. Arrhythmogenic right ventricular cardiomyopathy: new insights into mechanisms of disease. Cardiovasc Pathol 2010;19:166-70.
25 Quarta G, Muir A, Pantazis A, Syrris P, Gehmlich K, Garcia-Pavia P, Ward D, Sen-Chowdhry S, Elliott PM, McKenna WJ. Familial evaluation in arrhythmogenic right ventricular cardiomyopathy: impact of genetics and revised task force criteria. Circulation 2011;123:2701-9.

26 Sen-Chowdhry S, Syrris P, Ward D, Asimaki A, Sevdalis E, McKenna WJ. Clinical and genetic characterization of families with arrhythmogenic right ventricular dysplasia/cardiomyopathy provides novel insights into patterns of disease expression. Circulation 2007;115:1710-20.

27 Sen-Chowdhry S, Syrris P, Pantazis A, Quarta G, McKenna WJ, Chambers JC. Mutational heterogeneity, modifier genes, and environmental influences contribute to phenotypic diversity of arrhythmogenic cardiomyopathy. Circ Cardiovasc Genet 2010;3:323-30.

28 McKoy G, Protonotarios N, Crosby A, Tsatsopoulou A, Anastasakis A, Coonar A, Norman M, Baboonian C, Jeffery S, McKenna WJ. Identification of a deletion in plakoglobin in arrhythmogenic right ventricular cardiomyopathy with palmoplantar keratoderma and woolly hair (naxos disease). Lancet 2000;355:2119-24.

29 Norgett EE, Hatsell SJ, Carvajal-Huerta L, Cabezas JC, Common J, Purkis PE, Whittock N, Leigh IM, Stevens HP, Kelsell DP. Recessive mutation in desmoplakin disrupts desmoplakin-intermediate filament interactions and causes dilated cardiomyopathy, woolly hair and keratoderma. Hum Mol Genet 2000;9:2761-6.

30 Awad MM, Dalal D, Tichnell C, James C, Tucker A, Abraham T, Spevak PJ, Calkins H, Judge DP. Recessive arrhythmogenic right ventricular dysplasia due to novel cryptic splice mutation in pkp2. Hum Mutat 2006;27:1157.

31 Oliva A, Brugada R, D'Aloja E, Boschi I, Partemi S, Brugada J, Pascali VL. State of the art in forensic investigation of sudden cardiac death. Am J Forensic Med Pathol 2011;32:1-16.

32 Tan HL, Hofman N, van Langen IM, van der Wal AC, Wilde AA. Sudden unexplained death: heritability and diagnostic yield of cardiological and genetic examination in surviving relatives. Circulation 2005;112:207-13.

33 Zhang M, Tavora F, Oliveira JB, Li L, Franco M, Fowler D, Zhao Z, Burke A. Pkp2 mutations in sudden death from arrhythmogenic right ventricular cardiomyopathy (arvc) and sudden unexpected death with negative autopsy (sudna). Circ $\int$ 2012;76:189-94.

34 Xu T, Yang Z, Vatta M, Rampazzo A, Beffagna G, Pillichou K, Scherer SE, Saffitz J, Kravitz J, Zareba W, Danieli GA, Lorenzon A, Nava A, Bauce B, Thiene G, Basso C, Calkins H, Gear K, Marcus F, Towbin JA. Compound and digenic heterozygosity contributes to arrhythmogenic right ventricular cardiomyopathy. J Am Coll Cardiol 2010;55:587-97.

35 van der Zwaag PA, Jongbloed JD, van den Berg MP, van der Smagt JJ, Jongbloed R, Bikker H, Hofstra RM, van Tintelen JP. A genetic variants database for arrhythmogenic right ventricular dysplasia/cardiomyopathy. Hum Mutat 2009;30:1278-83.

36 Tiso N, Stephan DA, Nava A, Bagattin A, Devaney JM, Stanchi F, Larderet G, Brahmbhatt B, Brown K, Bauce B, Muriago M, Basso C, Thiene G, Danieli GA, Rampazzo $A$. Identification of mutations in the cardiac ryanodine receptor gene in families affected with arrhythmogenic right ventricular cardiomyopathy type 2 (arvd2). Hum Mol Genet 2001;10:189-94.

37 Basso C, Bauce B, Corrado D, Thiene G. Pathophysiology of arrhythmogenic cardiomyopathy. Nat Rev Cardiol 2011;9:223-33.

38 Bauce B, Rampazzo A, Basso C, Mazzotti E, Rigato I, Steriotis A, Beffagna G, Lorenzon A, De Bortoli M, Pilichou K, Marra MP, Corbetti F, Daliento L, lliceto S, Corrado D, Thiene G, Nava A. Clinical phenotype and diagnosis of arrhythmogenic right ventricular cardiomyopathy in pediatric patients carrying desmosomal gene mutations. Heart Rhythm 2011;8:1686-95.

39 Kapplinger JD, Landstrom AP, Salisbury BA, Callis TE, Pollevick GD, Tester DJ, Cox MG, Bhuiyan Z, Bikker $H$, Wiesfeld AC, Hauer RN, van Tintelen JP, Jongbloed JD, Calkins H, Judge DP, Wilde AA, Ackerman MJ. Distinguishing arrhythmogenic right ventricular cardiomyopathy/dysplasia-associated mutations from background genetic noise. J Am Coll Cardiol 2011;57:2317-27.

40 Christensen AH, Benn M, Bundgaard H, Tybjaerg-Hansen A, Haunso S, Svendsen $\mathrm{JH}$. Wide spectrum of desmosomal mutations in danish patients with arrhythmogenic right ventricular cardiomyopathy. J Med Genet 2010;47:736-44.

41 Grossmann KS, Grund C, Huelsken J, Behrend M, Erdmann B, Franke WW, Birchmeier W. Requirement of plakophilin 2 for heart morphogenesis and cardiac junction formation. I Cell Biol 2004;167:149-60.

42 Gerull B, Heuser A, Wichter T, Paul M, Basson CT, McDermott DA, Lerman BB, Markowitz SM, Ellinor PT, MacRae CA, Peters S, Grossmann KS, Drenckhahn J, Michely B, Sasse-Klaassen S, Birchmeier W, Dietz R, Breithardt G, Schulze-Bahr E, Thierfelder L. Mutations in the desmosomal protein plakophilin-2 are common in arrhythmogenic right ventricular cardiomyopathy. Nat Genet 2004;36:1162-4.

43 Roberts J, Herkert J, Rutberg J, Nikkel S, Wiesfeld A, Dooijes D, Gow R, van Tintelen J, Gollob M. Detection of genomic deletions of pkp2 in arrhythmogenic right ventricular cardiomyopathy. Clin Genet 2012 Aug 13. doi: 10.1111/j.13990004.2012.01950.x. [Epub ahead of print].

44 Saito M, Tucker DK, Kohlhorst D, Niessen CM, Kowalczyk AP. Classical and desmosomal cadherins at a glance. J Cell Sci 2012;125:2547-52.

45 Greenwood MD, Marsden MD, Cowley CM, Sahota VK, Buxton RS. Exon-intron organization of the human type 2 desmocollin gene (dsc2): desmocollin gene 
structure is closer to "classical" cadherins than to desmogleins. Genomics 1997;44:330-5

46 Heuser A, Plovie ER, Ellinor PT, Grossmann KS, Shin JT, Wichter T, Basson CT, Lerman BB, Sasse-Klaassen S, Thierfelder L, MacRae CA, Gerull B. Mutant desmocollin-2 causes arrhythmogenic right ventricular cardiomyopathy. Am J Hum Genet 2006;79:1081-8.

47 Pilichou K, Nava A, Basso C, Beffagna G, Bauce B, Lorenzon A, Frigo G, Vettori A, Valente M, Towbin J, Thiene G, Danieli GA, Rampazzo A. Mutations in desmoglein-2 gene are associated with arrhythmogenic right ventricular cardiomyopathy. Circulation 2006;113:1171-9.

48 Awad MM, Dalal D, Cho E, Amat-Alarcon N, James C, Tichnell C, Tucker A, Russell SD, Bluemke DA, Dietz HC, Calkins H, Judge DP. Dsg2 mutations contribute to arrhythmogenic right ventricular dysplasia/cardiomyopathy. Am J Hum Genet 2006:79:136-42.

49 Uzumcu A, Norgett EE, Dindar A, Uyguner O, Nisli K, Kayserili H, Sahin SE, Dupont E, Severs NJ, Leigh IM, Yuksel-Apak M, Kelsell DP, Wollnik B. Loss of desmoplakin isoform i causes early onset cardiomyopathy and heart failure in a naxos-like syndrome. J Med Genet 2006;43:e5.

50 Rampazzo A, Nava A, Malacrida S, Beffagna G, Bauce B, Rossi V, Zimbello R Simionati B, Basso C, Thiene G, Towbin JA, Danieli GA. Mutation in human desmoplakin domain binding to plakoglobin causes a dominant form of arrhythmogenic right ventricular cardiomyopathy. Am J Hum Genet 2002;71:1200-6.

51 Yang Z, Bowles NE, Scherer SE, Taylor MD, Kearney DL, Ge S, Nadvoretskiy VV, DeFreitas G, Carabello B, Brandon LI, Godsel LM, Green KJ, Saffitz JE, Li H, Danieli GA, Calkins H, Marcus F, Towbin JA. Desmosomal dysfunction due to mutations in desmoplakin causes arrhythmogenic right ventricular dysplasia/ cardiomyopathy. Circ Res 2006;99:646-55.

52 Carvajal-Huerta L. Epidermolytic palmoplantar keratoderma with woolly hair and dilated cardiomyopathy. J Am Acad Dermatol 1998;39:418-21.

53 Alcalai R, Metzger S, Rosenheck S, Meiner V, Chajek-Shaul T. A recessive mutation in desmoplakin causes arrhythmogenic right ventricular dysplasia, skin disorder, and woolly hair. J Am Coll Cardiol 2003;42:319-27.

54 Fressart V, Duthoit G, Donal E, Probst V, Deharo JC, Chevalier P, Klug D, Dubourg $O$, Delacretaz E, Cosnay $P$, Scanu P, Extramiana F, Keller $D$, Hidden-Lucet F, Simon F, Bessirard V, Roux-Buisson N, Hebert JL, Azarine A, Casset-Senon D, Rouzet F, Lecarpentier $Y$, Fontaine $G$, Coirault C, Frank R, Hainque $B$, Charron P. Desmosomal gene analysis in arrhythmogenic right ventricular dysplasia/cardiomyopathy: spectrum of mutations and clinical impact in practice. Europace 2010;12:861-8.

55 Chalabreysse L, Senni F, Bruyere P, Aime B, Ollagnier C, Bozio A, Bouvagnet P. A new hypo/oligodontia syndrome: carvajal/naxos syndrome secondary to desmoplakin-dominant mutations. J Dent Res 2011;90:58-64.

56 Keller D, Stepowski D, Balmer C, Simon F, Guenthard J, Bauer F, Itin P, David N, Drouin-Garraud V, Fressart V. De novo heterozygous desmoplakin mutations leading to naxos-carvajal disease. Swiss Med Wkly 2012;142:w1370.

57 Protonotarios NI, Tsatsopoulou AA, Gatzoulis KA. Arrhythmogenic right ventricular cardiomyopathy caused by a deletion in plakoglobin (naxos disease). Card Electrophysiol Rev 2002;6:72-80.

58 Protonotarios N, Tsatsopoulou A, Anastasakis A, Sevdalis E, McKoy G, Stratos K, Gatzoulis K, Tentolouris K, Spiliopoulou C, Panagiotakos D, McKenna W, Toutouzas P. Genotype-phenotype assessment in autosomal recessive arrhythmogenic right ventricular cardiomyopathy (naxos disease) caused by a deletion in plakoglobin. J Am Coll Cardiol 2001;38:1477-84.

59 Kaplan SR, Gard JJ, Protonotarios N, Tsatsopoulou A, Spiliopoulou C, Anastasakis A, Squarcioni CP, McKenna WJ, Thiene G, Basso C, Brousse N, Fontaine G, Saffitz JE. Remodeling of myocyte gap junctions in arrhythmogenic right ventricular cardiomyopathy due to a deletion in plakoglobin (naxos disease). Heart Rhythm 2004;1:3-11.

60 Li ZL, Lilienbaum A, Butler-Browne G, Paulin D. Human desmin-coding gene: complete nucleotide sequence, characterization and regulation of expression during myogenesis and development. Gene 1989;78:243-54.

61 van Tintelen JP, Van Gelder IC, Asimaki A, Suurmeijer AJ, Wiesfeld AC, Jongbloed JD, van den Wijngaard A, Kuks JB, van Spaendonck-Zwarts KY, Notermans N, Boven L, van den Heuvel F, Veenstra-Knol HE, Saffitz JE, Hofstra RM, van den Berg MP. Severe cardiac phenotype with right ventricular predominance in a large cohort of patients with a single missense mutation in the des gene. Heart Rhythm 2009;6:1574-83.

62 Otten $E$, Asimaki A, Maass A, van Langen IM, Wal AV, de Jonge N, van den Berg MP, Saffitz JE, Wilde AA, Jongbloed JD, van Tintelen JP. Desmin mutations as a cause of right ventricular heart failure affect the intercalated disks. Heart Rhythm 2010;7:1058-64.

63 Lorenzon A, Beffagna G, Bauce B, De Bortoli M, Li Mura IE, Calore M, Dazzo E, Basso C, Nava A, Thiene G, Rampazzo A. Desmin mutations and arrhythmogenic right ventricular cardiomyopathy. Am J Cardiol 2013;111:400-5.

64 Doetschman T, Barnett JV, Runyan RB, Camenisch TD, Heimark RL, Granzier HL, Conway SJ, Azhar M. Transforming growth factor beta signaling in adult cardiovascular diseases and repair. Cell Tissue Res 2012;347:203-23.
65 Beffagna G, Occhi G, Nava A, Vitiello L, Ditadi A, Basso C, Bauce B, Carraro G, Thiene G, Towbin JA, Danieli GA, Rampazzo A. Regulatory mutations in transforming growth factor-beta3 gene cause arrhythmogenic right ventricular cardiomyopathy type 1. Cardiovasc Res 2005;65:366-73.

66 Heldin CH, Landstrom M, Moustakas A. Mechanism of tgf-beta signaling to growth arrest, apoptosis, and epithelial-mesenchymal transition. Curr Opin Cell Biol 2009;21:166-76.

67 Beffagna G, Occhi G, Nava A, Vitiello L, Ditadi A, Basso C, Bauce B, Carraro G, Thiene G, Towbin JA, Danieli GA, Rampazzo A. Regulatory mutations in transforming growth factor-beta3 gene cause arrhythmogenic right ventricular cardiomyopathy type 1. Cardiovasc Res 2005;65:366-73.

68 Merner ND, Hodgkinson KA, Haywood AF, Connors S, French VM, Drenckhahn JD, Kupprion C, Ramadanova K, Thierfelder L, McKenna W, Gallagher B, Morris-Larkin L, Bassett AS, Parfrey PS, Young TL. Arrhythmogenic right ventricular cardiomyopathy type 5 is a fully penetrant, lethal arrhythmic disorder caused by a missense mutation in the tmem43 gene. Am J Hum Genet 2008;82:809-21.

69 Haywood AF, Merner ND, Hodgkinson KA, Houston J, Syrris P, Booth V, Connors S, Pantazis A, Quarta G, Elliott P, McKenna W, Young TL. Recurrent missense mutations in tmem43 (arvd5) due to founder effects cause arrhythmogenic cardiomyopathies in the uk and canada. Eur Heart J 2012 (in press).

70 Burke B, Stewart CL. Life at the edge: the nuclear envelope and human disease. Nat Rev Mol Cell Biol 2002:3:575-85.

71 Carboni N, Sardu C, Cocco E, Marrosu G, Manzi RC, Nissardi V, Isola F, Mateddu A, Solla E, Maioli MA, Oppo V, Piras R, Coghe G, Lai C, Marrosu MG. Cardiac involvement in patients with lamin a/c gene mutations: a cohort observation. Muscle Nerve 2012;46:187-92.

72 Quarta G, Syrris P, Ashworth M, Jenkins S, Alapi K Zuborne, Morgan J, Muir A Pantazis A, McKenna WJ, Elliott PM. Mutations in the lamin $\mathrm{a} / \mathrm{c}$ gene mimic arrhythmogenic right ventricular cardiomyopathy. Eur Heart J 2012;33:1128-36.

73 Larsen MK, Nissen PH, Berge KE, Leren TP, Kristensen IB, Jensen HK, Banner J. Molecular autopsy in young sudden cardiac death victims with suspected cardiomyopathy. Forensic Sci Int 2012;219:33-8.

74 Anderson BR, Granzier HL. Titin-based tension in the cardiac sarcomere: molecular origin and physiological adaptations. Prog Biophys Mol Biol 2012;110:204-17.

75 Taylor M, Graw S, Sinagra G, Barnes C, Slavov D, Brun F, Pinamonti B, Salcedo EE, Sauer W, Pyxaras S, Anderson B, Simon B, Bogomolovas J, Labeit S, Granzier H, Mestroni L. Genetic variation in titin in arrhythmogenic right ventricular cardiomyopathy-overlap syndromes. Circulation 2011;124:876-85.

76 Herman DS, Lam L, Taylor MR, Wang L, Teekakirikul P, Christodoulou D, Conner L, DePalma SR, McDonough B, Sparks E, Teodorescu DL, Cirino AL, Banner NR, Pennell DJ, Graw S, Merlo M, Di Lenarda A, Sinagra G, Bos JM, Ackerman MJ, Mitchell RN, Murry CE, Lakdawala NK, Ho CY, Barton PJ, Cook SA, Mestroni L, Seidman JG, Seidman CE. Truncations of titin causing dilated cardiomyopathy. N Engl J Med 2012;366:619-28.

77 MacLennan DH, Asahi M, Tupling AR. The regulation of serca-type pumps by phospholamban and sarcolipin. Ann N Y Acad Sci 2003;986:472-80.

78 Cerra MC, Imbrogno S. Phospholamban and cardiac function: a comparative perspective in vertebrates. Acta Physiol (Oxf) 2012;205:9-25.

79 van der Zwaag PA, van Rijsingen IA, Asimaki A, Jongbloed JD, van Veldhuisen DJ, Wiesfeld AC, Cox MG, van Lochem LT, de Boer RA, Hofstra RM, Christiaans I, van Spaendonck-Zwarts KY, Deprez RH Lekanne Dit, Judge DP, Calkins H, Suurmeijer AJ, Hauer RN, Saffitz JE, Wilde AA, van den Berg MP, van Tintelen JP. Phospholamban r14del mutation in patients diagnosed with dilated cardiomyopathy or arrhythmogenic right ventricular cardiomyopathy: evidence supporting the concept of arrhythmogenic cardiomyopathy. Eur J Heart Fail 2012;14:1199-207.

80 Posch MG, Perrot A, Geier C, Boldt LH, Schmidt G, Lehmkuhl HB, Hetzer R, Dietz R, Gutberlet M, Haverkamp W, Ozcelik C. Genetic deletion of arginine 14 in phospholamban causes dilated cardiomyopathy with attenuated electrocardiographic amplitudes. Heart Rhythm 2009;6:480-6.

81 Garcia-Pavia P, Syrris P, Salas C, Evans A, Mirelis JG, Cobo-Marcos M, Vilches C, Bornstein B, Segovia J, Alonso-Pulpon L, Elliott PM. Desmosomal protein gene mutations in patients with idiopathic dilated cardiomyopathy undergoing cardiac transplantation: a clinicopathological study. Heart 2011;97:1744-52.

82 Hodgkinson K, Connors S, Merner N, Haywood A, Young TL, McKenna W, Gallagher B, Curtis F, Bassett A, Parfrey P. The natural history of a genetic subtype of arrhythmogenic right ventricular cardiomyopathy caused by a p.\$358I mutation in tmem43. Clin Genet 2012 Jun 22. doi: 10.1111/j.1399-0004.2012.01919.x. [Epub ahead of print]

83 Yamada S, Pokutta S, Drees F, Weis WI, Nelson WJ. Deconstructing the cadherin-catenin-actin complex. Cell 2005;123:889-901.

84 Janssens B, Goossens S, Staes K, Gilbert B, van Hengel J, Colpaert C, Bruyneel E, Mareel M, van Roy F. Alphat-catenin: a novel tissue-specific beta-catenin-binding protein mediating strong cell-cell adhesion. J Cell Sci 2001;114:3177-88.

85 Smith JD, Meehan MH, Crean J, McCann A. Alpha t-catenin (ctnna3): a gene in the hand is worth two in the nest. Cell Mol Life Sci 2011:68:2493-8.

86 Maiden SL, Hardin J. The secret life of alpha-catenin: moonlighting in morphogenesis. J Cell Biol 2011:195:543-52. 
87 Drees F, Pokutta S, Yamada S, Nelson WJ, Weis WI. Alpha-catenin is a molecular switch that binds e-cadherin-beta-catenin and regulates actin-filament assembly. Cell 2005;123:903-15.

88 Janssens B, Mohapatra B, Vatta M, Goossens S, Vanpoucke G, Kools P, Montoye T, van Hengel J, Bowles NE, van Roy F, Towbin JA. Assessment of the ctnna3 gene encoding human alpha t-catenin regarding its involvement in dilated cardiomyopathy. Hum Genet 2003;112:227-36.

89 Li J, Goossens S, van Hengel J, Gao E, Cheng L, Tyberghein K, Shang X, De Rycke R, van Roy F, Radice GL. Loss of alphat-catenin alters the hybrid adhering junctions in the heart and leads to dilated cardiomyopathy and ventricular arrhythmia following acute ischemia. J Cell Sci 2012;125:1058-67.

90 van Hengel J, Calore M, Bauce B, Dazzo E, Mazzotti E, De Bortoli M, Lorenzon A, Li Mura IE, Beffagna G, Rigato I, Vleeschouwers M, Tyberghein K, Hulpiau P, van Hamme E, Zaglia T, Corrado D, Basso C, Thiene G, Daliento L, Nava A, van Roy F, Rampazzo A. Mutations in the area composita protein alphat-catenin are associated with arrhythmogenic right ventricular cardiomyopathy. Eur Heart J 2012;34:201-10.

91 Li D, Ahmad F, Gardner MJ, Weilbaecher D, Hill R, Karibe A, Gonzalez O, Tapscott T, Sharratt GP, Bachinski LL, Roberts R. The locus of a novel gene responsible for arrhythmogenic right-ventricular dysplasia characterized by early onset and high penetrance maps to chromosome 10p12-p14. Am J Hum Genet 2000;66:148-56.

92 Severini GM, Krajinovic M, Pinamonti B, Sinagra G, Fioretti P, Brunazzi MC Falaschi A, Camerini F, Giacca M, Mestroni L. A new locus for arrhythmogenic right ventricular dysplasia on the long arm of chromosome 14. Genomics 1996;31:193-200

93 Meurs KM, Mauceli E, Lahmers S, Acland GM, White SN, Lindblad-Toh K. Genome-wide association identifies a deletion in the $3^{\prime}$ untranslated region of striatin in a canine model of arrhythmogenic right ventricular cardiomyopathy. Hum Genet 2010;128:315-24.

94 Christensen AH, Benn M, Tybjaerg-Hansen A, Haunso S, Svendsen JH. Screening of three novel candidate genes in arrhythmogenic right ventricular cardiomyopathy. Genet Test Mol Biomarkers 2011;15:267-71.

95 Friedrich FW, Dilanian G, Khattar P, Juhr D, Gueneau L, Charron P, Fressart V, Vilquin JT, Isnard R, Gouya L, Richard P, Hammoudi N, Komajda M, Bonne G, Eschenhagen $T$, Dubourg $\mathrm{O}$, Villard $\mathrm{E}$, Carrier $\mathrm{L}$. A novel genetic variant in the transcription factor islet- 1 exerts gain of function on myocyte enhancer factor $2 c$ promoter activity. Eur J Heart Fail 2012 Nov 14. [Epub ahead of print].

96 Maron BJ, Towbin JA, Thiene G, Antzelevitch C, Corrado D, Arnett D, Moss AJ, Seidman $C E$, Young JB. Contemporary definitions and classification of the cardiomyopathies: an american heart association scientific statement from the council on clinical cardiology, heart failure and transplantation committee; quality of care and outcomes research and functional genomics and translational biology interdisciplinary working groups; and council on epidemiology and prevention. Circulation 2006:113:1807-16.

97 Elliott P, Andersson B, Arbustini E, Bilinska Z, Cecchi F, Charron P, Dubourg O, Kuhl U, Maisch B, McKenna WJ, Monserrat L, Pankuweit S, Rapezzi C, Seferovic P, Tavazzi L, Keren A. Classification of the cardiomyopathies: a position statement from the european society of cardiology working group on myocardial and pericardial diseases. Eur Heart J 2008;29:270-6.

98 Sen-Chowdhry S, Morgan RD, Chambers JC, McKenna WJ. Arrhythmogenic cardiomyopathy: etiology, diagnosis, and treatment. Annu Rev Med 2010;61: 233-53.

99 Campuzano O, Alcalde M, Berne P, Castro V, Guzzo G, Iglesias A, Alonso-Pulpon L, Garcia-Pavia P, Brugada J, Brugada R. Genetic testing of candidate genes in arrhythmogenic right ventricular cardiomyopathy/dysplasia. Eur J Med Genet 2012;55:225-34.

100 Casey G, Conti D, Haile R, Duggan D. Next generation sequencing and a new era of medicine. Gut 2012 May 1. [Epub ahead of print].

101 Polychronakos C, Seng KC. Exome diagnostics: already a reality? J Med Genet 2011;48:579.

102 Shamseldin HE, Alshammari M, Al-Sheddi T, Salih MA, Alkhalidi H, Kentab A, Repetto GM, Hashem M, Alkuraya FS. Genomic analysis of mitochondrial diseases in a consanguineous population reveals novel candidate disease genes. J Med Genet 2012:49:234-41.

103 Haack TB, Haberberger B, Frisch EM, Wieland T, luso A, Gorza M, Strecker V, Graf E, Mayr JA, Herberg U, Hennermann JB, Klopstock T, Kuhn KA, Ahting U, Sperl W, Wilichowski E, Hoffmann GF, Tesarova M, Hansikova H, Zeman J, Plecko B, Zeviani M, Wittig I, Strom TM, Schuelke M, Freisinger P, Meitinger T, Prokisch H. Molecular diagnosis in mitochondrial complex i deficiency using exome sequencing. J Med Genet 2012;49:277-83.

104 Futema M, Plagnol V, Whittall RA, Neil HA, Humphries SE. Use of targeted exome sequencing as a diagnostic tool for familial hypercholesterolaemia. J Med Genet 2012:49:644-9.

105 Hedberg C, Melberg A, Kuhl A, Jenne D, Oldfors A. Autosomal dominant myofibrillar myopathy with arrhythmogenic right ventricular cardiomyopathy 7 is caused by a des mutation. Eur J Hum Genet 2012;20:984-5.

106 Allegue C, Gil R, Sanchez-Diz P, Torres M, Quintela I, Carracedo A, Brion M. A new approach to long qt syndrome mutation detection by sequenom massarray system. Electrophoresis 2010;31:1648-55.
107 Brion M, Allegue C, Gil R, Blanco-Verea A, Carracedo A, Pagannone E, Evangelista A, Di Castro S, Marchitti S, Stanzione R, Volpe M, Rubattu S. Identification of a novel mybpc3 gene variant in a patient with hypertrophic cardiomyopathy. Ann Clin Lab Sci 2010;40:285-9.

108 Marcus Fl, Zareba W, Calkins H, Towbin JA, Basso C, Bluemke DA, Estes NA 3rd, Picard MH, Sanborn D, Thiene G, Wichter T, Cannom D, Wilber DJ, Scheinman M, Duff H, Daubert J, Talajic M, Krahn A, Sweeney M, Garan H, Sakaguchi S, Lerman BB, Kerr C, Kron J, Steinberg JS, Sherrill D, Gear K, Brown M, Severski P, Polonsky S, McNitt S. Arrhythmogenic right ventricular cardiomyopathy/dysplasia clinical presentation and diagnostic evaluation: results from the north american multidisciplinary study. Heart Rhythm 2009;6:984-92.

109 van Tintelen JP, Entius MM, Bhuiyan ZA, Jongbloed R, Wiesfeld AC, Wilde AA van der Smagt J, Boven LG, Mannens MM, van Langen IM, Hofstra RM, Otterspoor LC, Doevendans PA, Rodriguez LM, van Gelder IC, Hauer RN. Plakophilin-2 mutations are the major determinant of familial arrhythmogenic right ventricular dysplasia/cardiomyopathy. Circulation 2006;113:1650-8.

110 Delmar M, McKenna WJ. The cardiac desmosome and arrhythmogenic cardiomyopathies: from gene to disease. Circ Res 2010;107:700-14.

111 Desai BV, Harmon RM, Green KJ. Desmosomes at a glance. J Cell Sci 2009;122:4401-7.

112 Rasmussen TB, Hansen J, Nissen PH, Palmfeldt J, Dalager S, Jensen UB, Kim WY, Heickendorff L, Molgaard H, Jensen HK, Sorensen KE. Protein expression studies of desmoplakin mutations in cardiomyopathy patients reveal different molecular disease mechanisms. Clin Genet 2012 Nov 8. doi: 10.1111/cge.12056. [Epub ahead of print].

113 Cox MG, van der Zwaag PA, van der Werf C, van der Smagt JJ, Noorman M, Bhuiyan ZA, Wiesfeld AC, Volders PG, van Langen IM, Atsma DE, Dooijes D, van den Wijngaard A, Houweling AC, Jongbloed JD, Jordaens L, Cramer MJ Doevendans PA, de Bakker JM, Wilde AA, van Tintelen JP, Hauer RN Arrhythmogenic right ventricular dysplasia/cardiomyopathy: pathogenic desmosome mutations in index-patients predict outcome of family screening: dutch arrhythmogenic right ventricular dysplasia/cardiomyopathy genotype-phenotype follow-up study. Circulation 2011;123:2690-700.

114 Bauce B, Basso C, Rampazzo A, Beffagna G, Daliento L, Frigo G, Malacrida S, Settimo L, Danieli G, Thiene G, Nava A. Clinical profile of four families with arrhythmogenic right ventricular cardiomyopathy caused by dominant desmoplakin mutations. Eur Heart J 2005;26:1666-75.

115 Syrris P, Ward D, Asimaki A, Evans A, Sen-Chowdhry S, Hughes SE, McKenna WJ. Desmoglein-2 mutations in arrhythmogenic right ventricular cardiomyopathy: a genotype-phenotype characterization of familial disease. Eur Heart J 2007;28:581-8.

116 Sen-Chowdhry S, Syrris P, McKenna WJ. Desmoplakin disease in arrhythmogenic right ventricular cardiomyopathy: early genotype-phenotype studies. Eur Heart J 2005;26:1582-4.

117 den Haan AD, Tan BY, Zikusoka MN, Llado LI, Jain R, Daly A, Tichnell C, James C, Amat-Alarcon N, Abraham T, Russell SD, Bluemke DA, Calkins $H_{\text {, }}$ Dalal D, Judge DP. Comprehensive desmosome mutation analysis in north americans with arrhythmogenic right ventricular dysplasia/cardiomyopathy. Circ Cardiovasc Genet 2009;2:428-35.

118 Bauce B, Nava A, Beffagna G, Basso C, Lorenzon A, Smaniotto G, De Bortoli M, Rigato I, Mazzotti E, Steriotis A, Marra MP, Towbin JA, Thiene G, Danieli GA, Rampazzo A. Multiple mutations in desmosomal proteins encoding genes in arrhythmogenic right ventricular cardiomyopathy/dysplasia. Heart Rhythm 2010;7:22-9.

119 Bhuiyan ZA, Jongbloed JD, van der Smagt J, Lombardi PM, Wiesfeld AC, Nelen M, Schouten M, Jongbloed $R$, Cox MG, van Wolferen M, Rodriguez LM, van Gelder IC, Bikker H, Suurmeijer AJ, van den Berg MP, Mannens MM, Hauer RN, Wilde AA, van Tintelen JP. Desmoglein-2 and desmocollin-2 mutations in dutch arrhythmogenic right ventricular dysplasia/cardiomypathy patients: results from a multicenter study. Circ Cardiovasc Genet 2009;2:418-27.

120 Nakajima T, Kaneko Y, Irie T, Takahashi R, Kato T, lijima T, Iso T, Kurabayashi M. Compound and digenic heterozygosity in desmosome genes as a cause of arrhythmogenic right ventricular cardiomyopathy in japanese patients. Circ $J$ 2012;76:737-43.

121 Barahona-Dussault C, Benito B, Campuzano O, Iglesias A, Leung TL, Robb L, Talajic M, Brugada R. Role of genetic testing in arrhythmogenic right ventricular cardiomyopathy/dysplasia. Clin Genet 2010;77:37-48.

122 Hershberger RE, Cowan J, Morales A, Siegfried JD. Progress with genetic cardiomyopathies: screening, counseling, and testing in dilated, hypertrophic, and arrhythmogenic right ventricular dysplasia/cardiomyopathy. Circ Heart Fail 2009:2:253-61.

123 Charron P, Arad M, Arbustini E, Basso C, Bilinska Z, Elliott P, Helio T, Keren A, McKenna WJ, Monserrat L, Pankuweit S, Perrot A, Rapezzi C, Ristic A, Seggewiss $H$, van Langen I, Tavazzi L. Genetic counselling and testing in cardiomyopathies: a position statement of the european society of cardiology working group on myocardial and pericardial diseases. Eur Heart $J$ 2010;31:2715-26.

124 Ghosh N, Haddad H. Recent progress in the genetics of cardiomyopathy and its role in the clinical evaluation of patients with cardiomyopathy. Curr Opin Cardiol 2011:26:155-64. 